\title{
A NEW LOOK AT AN OLD QUESTION - PRECISELY WHERE DOES A CAUSE OF ACTION BASED ON CONTRACT OR DELICT “ARISE” IN THE CASE OF CIVIL CLAIMS IN THE MAGISTRATES' AND SMALL CLAIMS COURTS?
}

David Hulme

$B A \quad L L B \quad L L M$

Senior Lecturer of Law

University of KwaZulu-Natal, Durban

Attorney of the High Court of South Africa

Stephen Peté

BA LLB LLM MPhil

Associate Professor of Law

University of KwaZulu-Natal, Durban

Attorney of the High Court of South Africa

\section{SUMMARY}

One of the chief jurisprudential considerations of the new South Africa must be access to justice. Whilst various possibilities for the realization of this imperative are aired periodically, the principles on which the civil jurisdiction of the courts is based are seldom considered in this regard. However, complex and arcane rules of jurisdiction can place what this article argues to be unfair and largely pointless limitations on a plaintiff, particularly in respect of magistrates' and small claims courts actions. Section 28(1)(d) of the Magistrates' Courts Act, for example, which confers jurisdiction on a court in relation to the locality of the cause of action, can prove particularly problematic in the case of claims based on contract. Jurisdiction cannot be conferred under this provision unless every "element" of the contract - offer acceptance, performance and/or breach, has occurred within the same magisterial district. This article examines the many practical problems which arise as a result, as well as various interpretations of the existing case law, which may serve to alleviate these problems to a certain extent. The authors conclude, however, that legislative reform may be the only way in which to truly solve the many dilemmas which arise in practice. 


\section{$1 \quad$ INTRODUCTION}

An imperative within post-apartheid South Africa is to improve access to justice. ${ }^{1}$ Proposals as to the different ways in which this important goal may be achieved usually include provisions aimed at reducing the costs of litigation, providing free legal advice for the indigent, speeding up and simplifying legal proceedings, correcting the incompetent administration of the courts, or improving the service provided by the legal profession. ${ }^{2}$ The issue of the civil jurisdiction of the courts is seldom considered in relation to access to justice. ${ }^{3}$ It is the contention of this article that, in certain cases, complex and arcane rules of jurisdiction operate so as to hinder access to justice by both poor and middle-class plaintiffs.

On the one hand, it is clearly necessary for the rules of jurisdiction to ensure that there is a firm link between a particular matter at hand and the specific court dealing with that matter. Litigants should not be entitled to "shop" for whichever particular forum happens to suit them at the time. Were "forum shopping" to be allowed, a plaintiff motivated by malice could select a court purely on the basis that it was so remote that it was bound to cause great inconvenience to his or her opponent.

On the other hand, the rules of jurisdiction should not serve to stifle the legal process. It is submitted that there is a great deal of artificiality, not to mention arbitrariness, when it comes to the issue of jurisdiction. ${ }^{4}$ Furthermore, there are significant areas of the law relating to jurisdiction which are characterized by uncertainty and confusion. ${ }^{5}$

Discussion on this topic formed a significant part of the Judicial Conference held in July 2009.

2 It has been suggested, eg, that the service provided by the legal profession may be improved by removing the distinction between attorneys and advocates. This suggestion was made by President Zuma at the conference referred to in fn 1 above.

3 This article deals with the civil jurisdiction of the courts and it is accordingly civil rather than criminal justice to which the authors refer.

4 In some cases, the need to be practical results in some degree of artificiality. Eg, jurisdiction based on the place of residence or domicile of the defendant, is reckoned at the time of service of summons, and remains valid despite the fact that the defendant may move away from the particular court's area of jurisdiction during the course of the action. See Pistorius Pollak on Jurisdiction 2ed (1993) 12-14. Another example is to be found in the attachment of the property of a foreign peregrine, to either found or confirm jurisdiction. If such property is destroyed subsequent to the attachment, the court which acquired jurisdiction by virtue of the attachment retains it. Clearly, in both the examples provided, the principle of effectiveness would no longer apply, but the law is content to maintain the fiction that the jurisdiction of the court concerned remains intact. Furthermore, in general terms, it is submitted that with the advent of s 112 of the South Africa Act 1909 (9 Edw VII Ch9 s95) and subsequent legislation dealing with the issue of service of court process, effectiveness is no longer an issue in relation to matters involving defendants who are local peregrini, since the judgment of any South African court is enforceable throughout the Republic. This legislative extension of the effectiveness of our courts, however, has not been translated into an extension of their jurisdictional powers. See s 26 of the Supreme Court Act 59 of 1959; s 4(3) of the Magistrates' Courts Act; Pistorius 38-40; and Ewing McDonald \& Co Ltd $\checkmark$ M\&M Products Co 1991 1 SA 252 (A).

5 Note, eg, the following comments of Van Reenen $\mathrm{J}$ in Thomas $v$ BMW South Africa (Pty) Ltd 19962 SA 106 (C) 118G, which relate to the jurisdictional principles to be applied in an action based on delict: "Except for Pollak (op cit at 80 ) who, relying on Jackson $v$ Spittall 
When it comes to jurisdiction in the High Courts, a generally liberal attitude adopted by the courts with regard to this issue, together with a reasonably adequate number of rationes jurisdictiones (that is, the different "grounds" on which High Court jurisdiction is based), means that certain of the problems caused by artificiality, arbitrariness and confusion, may be circumvented. ${ }^{6}$ This is not the case in relation to jurisdiction in the magistrates' and small claims courts. The Magistrates' Courts Act sets out what would seem to be clear and detailed jurisdictional rules for the magistrates' courts and, in terms of the Small Claims Courts Act, virtually identical jurisdictional provisions apply in the case of the small claims courts. ${ }^{7}$ The problem, however, is that certain of these rules are somewhat restrictive and, arguably, place what could be regarded as unfair and largely pointless limitations on a plaintiff. For example, the rules of jurisdiction relating to the magistrates' and small claims courts do not seem to take into account that in this age of shopping malls and business/industrial parks, the majority of people, particularly those who are middle class, no longer contract or do business within their immediate residential locality. ${ }^{8}$ Further complications arise due to the fact that, in many cases, one is acting against an artificial juristic person such as a company, which may give rise to further jurisdictional problems for the average plaintiff.

It is submitted that the restrictive nature of the magistrates' and small claims courts' jurisdictional provisions needs to be addressed with some

(1870) LR 5 CP 542 (a breach of contract case), suggested that the act of the defendant in a court's area of jurisdiction which gives a plaintiff his cause of complaint determines the court which has jurisdiction, the authors of South African textbooks on jurisdiction, save for qualified criticism of the former's view because of its lack of general applicability, have not provided any guidance in regard to the question whether all the elements of a cause of action, more particularly a delict, should arise in a court's area for it to have jurisdiction. Save that it is generally accepted that in the case of the Supreme Court, by contrast with the magistrate's court, it is not necessary for all the facta probanda of a cause of action to have occurred within its area of jurisdiction for it to be able to assume jurisdiction (see Pistorius (op cit at 63); Forsyth (op cit at $171 \mathrm{fn} 240$ ); The Law of South Africa vol 11 para $411 \mathrm{fn} 1$ ) there is not much clarity in South African law where elements of a cause of action arise in or transcend different areas of jurisdiction." See also Beck "A Jurisdictional Conundrum" 1985 THRHR 305314.

6 There have been several instances in which our courts have adopted a more liberal approach to jurisdiction during the course of the last half century. One example is the fact that, in certain cases, considerations of convenience have been taken into account in relation to jurisdiction. See, eg, Sonia (Pty) Ltd v Wheeler 19581 SA 555 (A); and Estate Agents Board v Lek 19793 SA 1048 (A) 1069D-G. During the early 1980s there was a fair amount of academic debate on this issue. See Taitz "Jurisdiction and Forum Conveniens A New Approach" 1980 THRHR 187; Spiro "Forum non Conveniens" 1980 CILSA 333; Taitz "Jurisdiction and Forum Conveniens - A Reply" 1981 THRHR 372; and Beck 1985 THRHR 305. The last-mentioned author disapproved of the development, inter alia because it appeared to have no basis in law, might lead to abuse and create uncertainty. See Beck 1985 THRHR 317. If the practice was to be retained, he argued that a court should exercise jurisdiction as a matter of convenience only where two claims were inextricably interwoven He submitted that there was absolutely no authority for the proposition that "a plaintiff may sue in a particular court merely because it is convenient for him to do so". See Beck 1985 THRHR 311.

7 See the Magistrates' Courts Act 32 of 1944; and ss 14, 15, 16, 17, 23 and 24 of the Small Claims Courts Act.

8 See the remarks of Van Reenen $\mathrm{J}$ in Thomas v BMW South Africa (PTY) LTD supra. 
urgency. Even large corporations struggle with issues concerning jurisdiction. ${ }^{9}$ The problem is even worse in the case of "petty" litigants, however, since often such litigants cannot afford to risk the wasted time and cost of pursuing a relatively small claim, in circumstances in which difficulties over jurisdiction pose a substantial hurdle, which needs to be overcome before the merits of the matter are even considered.

For the reasons set out above, this article will focus particularly on magistrates' and small claims courts' jurisdiction. Furthermore, it will focus on those causes of action founded upon the law of contract and the law of delict, since these are by far the most common causes of action in civil matters. The article will grapple with the jurisdictional difficulties created by the wording of section 28 of the Magistrates' Courts Act, together with the interpretation of this wording by our courts over the years. It will suggest various methods by means of which magistrates' and small claims courts' jurisdiction may be released from what we shall term a "jurisdictional straight-jacket".

\section{SETTING THE SCENE}

Let us set the scene by sketching a simple factual scenario, illustrating how easily problems may arise in practice on the issue of magistrates' and small claims court jurisdiction. Consider the difficulties faced by the average resident of an upper middle-class suburb such as Durban North. This district falls within the area of jurisdiction of the Durban magistrate's court, but its residents do much of their shopping in neighbouring Umhlanga, a district which falls under the jurisdiction of the Verulam magistrate's court.

Assume that the resident concerned orders tiles to the value of R5000-00 from a dealer who has a branch in Umhlanga. Assume also that, like many businesses in the formal sector, the dealer is a company or close corporation. The agreement is concluded at the dealer's Umhlanga premises, with the goods to be delivered to the resident's home in Durban North. Assume that the dealer has another branch of its business in Port Shepstone on the South Coast of KwaZulu-Natal. The resident pays R5 000 to the dealer, but the goods fail to arrive. The dealer begins by making excuses for late delivery, then begins to avoid the resident's calls and finally ignores a letter of demand despatched by the resident's attorney. Notwithstanding the element of fraud evident in the dealer's conduct, the police are uninterested as they claim that this is a civil matter to be resolved between the parties. The local newspaper's consumer assistance writer is inundated with similar complaints and elects not to follow up on this particular matter. As the dealer would possibly foresee, the resident's attorney eventually advises the resident to proceed with the matter in the

9 Note, for instance, the cases in which it was held that the doctrine of effectiveness is not the only basis on which a court will enjoy jurisdiction; - Venetia Mineraria Spa v Carolina Collieries (Pty) Ltd (in liquidation) 19874 SA 883 (A) 891C; and Ewing McDonald \& Co Ltd v M\&M Products Co supra 260B. 
small claims court, as the amount involved does not make the attorney's involvement economically viable.

The intention behind the creation of the small claims courts was to provide a cheap and effective alternative to the magistrates' courts for small claims. ${ }^{10}$ In order to ensure that litigation in these courts remains inexpensive, legal representatives are not permitted. ${ }^{11}$ However, proceeding in the small claims courts is not as simple as it may seem, with the problem of jurisdiction being first on the potential plaintiff's list of difficulties to be confronted. $^{12}$ As has been noted above, the jurisdictional sections of the Magistrates' Court Act have been reproduced with little discernible change in the Small Claims Court Act, meaning that the same jurisdictional problems which arise in the magistrates' courts will affect litigants in the small claims courts also. ${ }^{13}$ In this particular example, the plaintiff would have to sue either where the cause of action could legally be said to have "wholly" arisen; or where the company or close corporation could legally be said to "reside" or "carry on business". ${ }^{14}$ It is at this point that the plaintiff confronts a range of jurisdictional problems, each of which requires closer examination of the legislation regulating jurisdiction in the small claims courts and the magistrates' courts:

\section{SECTIONS 28(1)(a) AND (d) OF THE MAGISTRATES' COURTS ACT}

Since the provisions of sections 14(1)(a) and (d) of the Small Claims Courts Act, which would be utilized by the plaintiff in the example sketched above, are essentially identical to the provisions of sections 28(1)(a) and (d) of the Magistrates' Courts Act, in the discussion which follows we have elected to refer only to the provisions of the latter Act.

10 See the introduction to the small claims courts section of the Department of Justice and Constitutional Development website "The Small Claims Court (sic) allows you to institute minor civil claims in a speedy, affordable and simple manner without using an attorney." (http://www.justice.gov.za/scc/scc.htm). The current jurisdiction of these courts includes claims to the value of R12 000-00 in terms of s 15(a), as compared with R100 000-00 and R300 000-00 in the district and regional magistrates' courts respectively.

11 S 7 of the Small Claims Courts Act 61 of 1984.

12 Depending on the specific court in question, problems relating to litigation in the small claims courts may include, inter alia: (a) waiting in long queues whilst the court clerks interview plaintiffs and draft letters of demand or summonses; (b) the inability of the said court clerks to summarize the plaintiff's cause of action accurately in written form; (c) the unwillingness of certain clerks to accept, for the purpose of issue, letters of demand or particulars of claim drafted by the plaintiff's attorneys or legal aid clinics; (d) the plaintiff's inability, due to unfamiliarity with the procedures involved, to select and instruct the relevant sheriff of the magistrates' courts, so as to ensure the service of the summons. These problems warrant further attention but do not form part of this paper and will not be dealt with here.

13 S 14 of the Small Claims Courts Act is the direct equivalent of $s 28$, and there are no material differences in the wording.

14 S 28 of the Magistrates' Court Act, or the identically worded s 14 of the Small Claims Courts Act. 
Section 28(1) of the Magistrates' Courts Act provides, inter alia, that: -

"the persons in respect of whom the court shall have jurisdiction shall be the following and no other -

(a) any person who resides, carries on business or is employed within the district; ...

(d) any person, whether or not he resides, carries on business or is employed within the district, if the cause of action arose wholly within the district."

Sections 28(1) (a) and (d) are almost certainly the most frequently used provisions for determining which specific magistrate's court will have jurisdiction in matters falling within the overall jurisdiction of the magistrates' courts. ${ }^{15}$ In each case the phrase "any person" effectively refers to the defendant.

\section{Proceeding in terms of section 28(1)(a)}

Bearing in mind the factual scenario outlined earlier, let us first consider the problems which may arise when attempting to proceed in terms of section $28(1)(a) .{ }^{16}$ Since the defendant is a corporate body, and since it is difficult to conceive of a situation in which such an entity could be said to be "employed", the potential plaintiff will have to determine within which magisterial district the defendant "is resident" or "carries on business".

The law governing the "residence" of a corporate body was settled in Bisonboard Ltd $v K$ Braun Woodworking Machinery (Pty) Ltd. $^{17}$ In Bisonboard, the Appellate Division (the current Supreme Court of Appeal) decided that, like a natural person, a company may have dual residence for jurisdictional purposes. For a company, there are two possible "residences": its place of central control and its registered office. ${ }^{18} \mathrm{~A}$ company's place of central control is where its central administration is located and from where it carries on its real or principle business, in other words, its head office. ${ }^{19}$ In practice, it is not always easy to establish where a company's central administration is located, particularly if it operates from more than one location. Unless one has personal knowledge of where the head office of a company is located, or its location is clearly advertised, establishing which particular operational location houses the central administration of a company is often guesswork.

The whereabouts of a company's registered office, on the other hand, is easier to establish, since this information is kept by the Registrar of

15 S 29 determines the upper limit of the value of claims which may be brought within the magistrates' courts, whilst s 46 excludes certain types of claim from the magistrates' courts' jurisdiction. S 28, ss (b), (c), (e), (f) and (g) indicate which specific court has jurisdiction in respect of matters relating to partnerships, incidental proceedings, interpleader proceedings, consent, and immovable property respectively.

16 Or s 14(1) of the Small Claims Courts Act, as the case may be.

1719911 SA $482(\mathrm{~A})$.

18 Bisonboard Ltd v K Braun Woodworking Machinery (Pty) Ltd supra 495B-D.

19 ISM Inter Ltd v Maraldo 19834 SA 112 (T) 115-116. 
Companies (CIPRO). However, in order to obtain the address of the registered office, a plaintiff is obliged to conduct a search of the relevant register, or to have such a search conducted on his behalf. A plaintiff is unlikely to be in a position to do this unless he has some form of legal representation or assistance. This creates a problem for those plaintiffs who wish to pursue a claim for a small amount, such as that referred to in the factual scenario we sketched earlier, which might not warrant the initial outlay of fairly significant legal costs. In the case of a plaintiff who wishes to proceed in the small claims court, the costs involved may prove impossible to recover, since the Small Claims Courts Act provides no mechanism for the recovery of such costs, assuming that a plaintiff has the means to pay for the necessary legal services in the first place.

The above might not pose an insuperable difficulty, were plaintiffs able to make full use of the added ground for jurisdiction provided in section 28(1)(a), which affords jurisdiction to the magisterial district in which the defendant "carries on business". One would think that, in the case of a company, the phrase "carries on business" would include any place that the company does business, including the places where its branch offices are located. Regrettably, in Minister of Law \& Order v Patterson the Appellate Division held that a "place of business" for a company is only its principle place of business or the place in which its head office is situated. ${ }^{20}$ This restrictive interpretation means that this provision provides no further assistance to our putative plaintiff.

Let us assume, however, the plaintiff overcomes the difficulties referred to above and carries out the necessary company search. To return to the factual scenario we sketched earlier, let us assume that it is established that the tile suppliers are a close corporation whose registered office is in Port Shepstone. Once again, the plaintiff is hamstrung, since the time and costs involved in taking several trips to Port Shepstone, some one hundred and fifty kilometres south of Durban, to issue summons and attend a hearing, is not justified by the size of the claim. This leaves the possibility of proceeding in accordance with section 14(1)(d) of the Small Claims Courts Act, which is the equivalent of section 28(1)(d) of the Magistrates Courts Act.

\section{Proceeding in terms of section 28(1)(d)}

In terms of this section, a court will have jurisdiction if the cause of action arose wholly within the district. At first glance, it would seem to be a fairly simple matter to establish where a particular cause of action arose for jurisdictional purposes. One simply isolates the basic material facts upon

20 Minister of Law \& Order v Patterson 19842 SA 739 (A). Note that in General Accident Insurance Co SA Ltd v Mbonambi 19864 SA 967 (N) 969-971, Friedman J as he then was, expressed doubts about whether Patterson was correctly decided, and whether "place of business" ought to have such a restricted interpretation, but felt himself bound by its decision. It may seem surprising that this highly unsatisfactory state of affairs has remained as it has for over twenty years, but few civil claims falling within the jurisdiction of the magistrates' courts are worth the costs of an appeal, particularly when the purpose is to challenge an Appellate Division decision. 
which the particular cause of action is based and determines where each of these material facts occurred. ${ }^{21}$ This tells one where the cause of action arose, and enables one to tie the case to the area of jurisdiction of a particular court.

It is not, however, quite as simple as it seems. The plaintiff is faced with at least two interlinked problems: Firstly, he must distinguish between the "material facts" (that is, the so-called facta probanda) upon which his cause of action is based, and all the other facts (that is, the so-called facta probantia) which, although not material, provide evidence in support of the material facts. For example, in the case of a cause of action based on contract, both "offer" and "acceptance" are usually regarded as part of the facta probanda. However, it may, perhaps, be argued that these facts should be regarded as part of the facta probantia, which support the fact that a valid contract was concluded, that is, conclusion of the contract being regarded as the relevant material fact. The second problem faced by the plaintiff is that, for purposes of jurisdiction, the "material facts" must be tied to particular jurisdictional areas. It is at least arguable that the area to which one connects a particular "material fact" may change, depending upon the stage at which one looks at the "material fact" concerned. An "offer", for example may be made within a particular jurisdictional area, but continues in existence until it is accepted. For jurisdictional purposes, must the offer necessarily be linked to the jurisdictional area in which it was first made, or may it be linked to the jurisdictional area in which it exists at the time it is accepted?

\section{The significance of the word "wholly" in section 28(1)(d)}

While the questions posed above are important for litigation in any court, they are particularly significant in magistrates' courts practice, because section 28(1)(d) provides specifically that a cause of action must have occurred "wholly" within the jurisdiction of a particular court, if that court is to be afforded jurisdiction in terms of this provision. There is no such provision in the legislation dealing with jurisdiction in the High Courts. The Supreme Court Act merely provides that a court will have jurisdiction in respect of "all causes arising" within its jurisdiction. ${ }^{22}$ We submit that the inclusion of the word "wholly" in section $28(1)(d)$, as currently interpreted, unnecessarily restricts the jurisdiction afforded by section $28(1)(d)$ in magistrates' courts matters. In High Courts matters, the fact that all the elements of a cause of action may not have occurred within the jurisdiction of a single court will simply result in more than one court being afforded jurisdiction. Furthermore, there will always be at least one court that will enjoy jurisdiction on this

21 The material facts are known as the facta probanda as opposed to the facta probantia; the facts or evidence supporting the material facts.

22 S 19(1)(a) Supreme Court Act 59 of 1959. This has been held to reflect the common law position, which is what is followed in the High Courts (Ewing McDonald \& Co Ltd v M\&M Products Co supra 257E-G). 
ground. ${ }^{23}$ In magistrates' courts' practice, however, the result of the inclusion of the word "wholly" in section 28(1)(d) has been "all or nothing". As matters stand at present, if the material elements of a cause of action (as currently interpreted by our courts) occur within the jurisdictional areas of more than one court, no court will enjoy jurisdiction in terms of section $28(1)(d)$, and the use of section 28(1)(a), with all the difficulty that this implies, becomes obligatory.

\section{THE DEFINITION OF "CAUSE OF ACTION"}

The leading case in relation to the definition of the term "cause of action" is McKenzie v Farmers' Co-operative Meat Industries Ltd. ${ }^{24}$ In McKenzie, Maasdorp JA approved the definition given in the English case of Cook $v$ Gill which defined the phrase "cause of action arising in the city" as: "Every fact which it would be necessary for the plaintiff to prove, if traversed, in order to support his right to the judgment of the court." ${ }^{25}$ The court in Cook v Gill went on to add: "It does not comprise every piece of evidence which is necessary to prove each fact, but every fact which it is necessary to be proved." ${ }^{\prime 2}$ In the case of Abrahmse \& Sons $v$ SA Railways and Harbours, which was decided just over a decade after the McKenzie case, the court defined the expression "cause of action" as follows:

"The proper legal meaning of the expression 'cause of action' is the entire set of facts which give rise to an enforceable claim and includes every fact which is material to be proved to entitle a plaintiff to succeed in his claim. It includes all that a plaintiff must set out in his declaration to disclose a cause of action.'

For reasons that will become apparent later, we prefer the definition given in this latter case. In the meantime, however, we respectfully concur with the

23 It is not strictly correct to say that in the High Court it is sufficient for merely one element of a cause of action to occur within a court's jurisdiction in order for the court to have jurisdiction. It is still necessary for the matter to "arise" within the jurisdiction of a particular court, even if some of the elements take place within the jurisdiction of other courts (see Thomas $v$ BMW South Africa (Pty) Ltd supra 125B-E). Nevertheless, the various common law grounds upon which jurisdiction can be founded, such as the causa continentia rule together with the distinction that has been drawn between the ratio contractus and ratio solutionis, creates a situation for contractual matters where there is a reasonably wide choice of fora (see Roberts Construction Co Ltd v Wilcox Bros (Pty) Ltd 19624 SA 326 (A) $335 \mathrm{~A}-336 \mathrm{H})$. In delictual matters it rarely happens that a cause of action occurs in more than one court. However, the court in Thomas $v$ BMW held that the court in which the "locus" of a particular cause of action occurred would have jurisdiction and appeared to postulate the use of the causa continentia rule in the alternative $(127 \mathrm{H} / \mathrm{l}-128 \mathrm{~A} / \mathrm{B})$. The most significant point when making the comparison between High and Magistrates' Courts jurisdictional practice, however, is the following: In neither contractual nor in delictual matters will there be a situation in which no court will have jurisdiction based on the cause of action, merely because it did not take place "wholly" within the jurisdiction of a single court. The result is that in High Courts' practice a plaintiff is never left with the ratio domicilii as the only possible ground for jurisdiction.

24 McKenzie v Farmers' Co-operative Meat Industries Ltd 1922 AD 16.

25 McKenzie v Farmers' Co-operative Meat Industries Ltd supra 23; and Cook v Gill L.R. 8 C.P. 107.

26 We submit that there may well be difficulties relating to the definition enunciated by the court in Cook $v$ Gill, to which we will return in due course.

27 Abrahmse \& Sons v SA Railways and Harbours 1933 CPD 626633. 
distinction that the court in McKenzie drew between the material facts which the plaintiff or applicant is required to prove in order to establish his or her case (that is, the so called "facta probanda"), and the evidence which the plaintiff or applicant must advance in order to establish those material facts (that is, the so called "facta probantia"). What this amounts to is that the "cause of action" in a particular case consists of the "facta probanda" as opposed to the "facta probantia". In simple terms, what the court in the McKenzie case held is that the central basic facts of the case are not to be confused with the various items of evidence required to prove those facts.

Unfortunately, we find other aspects of the McKenzie judgment to be less satisfactory. It may be argued that the phrase "every fact which it would be necessary for the plaintiff to prove, if traversed, in order to support his right to the judgment of the court" makes "cause of action" a shifting concept, dependant on whatever part of the plaintiff's case is challenged in the defendant's pleadings. This is a point to which we shall return below.

\section{THE MATERIAL ELEMENTS COMPRISING A CAUSE OF ACTION IN RESPECT OF CONTRACTUAL CLAIMS}

Turning to contractual claims, such as the one in the practical example provided earlier, what are the material facts which constitute a cause of action based on contract? The leading reference book on civil procedure in the magistrates' courts states as follows:

"A plaintiff suing on a contract must ordinarily prove both the conclusion of the contract and its terms; he must also prove the breach to have occurred in the district. It follows then from the first requirement that both the offer and acceptance must have been made in the same district, and if they were not, then the whole cause of action cannot be said to have arisen in one district."

In other words, in a magistrate's court matter based on contract, the material facts are that a contract was concluded (which is divided into the material fact of the offer and the material fact of the acceptance) and that its terms were breached. Adopting this approach, in order to determine jurisdiction in relation to "cause of action arising", one simply determines where the offer was made, where the offer was accepted (leading to the conclusion of the contract), and where the terms of the contract were breached. ${ }^{29}$ According to this approach, all three places are relevant for purposes of establishing jurisdiction based upon "cause of action arising".

28 Jones and Buckle Civil Practice in the Magistrates Courts of South Africa Vol I the Act Erasmus and Van Loggerenberg (Juta Service 24 2010) 54-55, quoting Jonker $v$ Esterhuizen 1927 CPD 225227.

29 Of course, establishing the place or places where the offer was made and accepted may not be as easy as it seems. Eg, a person in Durban makes an offer on the telephone to a person in Cape Town. It is agreed that the offeree may consider the matter and mail his acceptance to the offeror by post. In this case, the place of the offer is Cape Town since, according to the so-called "information theory" of contract, the offer comes into existence at the time and place that it comes to the attention of the offeree, ie, in Cape Town. The place of the acceptance is the place the offeree mails his acceptance since, according to the so- 
The result of this is that there is always a good chance, particularly in the case of a contractual claim, that the cause of action may not have arisen "wholly within the district". This is indeed so in the case of the practical example we provided earlier. Since the agreement was concluded in the dealer's Umhlanga premises, with the goods to be delivered to the consumer's home in Durban North, the conclusion of the contract and the breach (that is, the failure to deliver the tiles), occurred within the jurisdiction of two separate courts, namely the Durban and Verulam magistrates' courts, which have jurisdiction over Durban North and Umhlanga respectively. Therefore, on the basis of the law as it currently stands, the cause of action did not arise wholly within the jurisdiction of a single court, and the plaintiff is precluded from using section $28(1)$ (d) to proceed in either of the nearest magistrates' courts, namely Durban or Verulam. He is obliged to utilize section 28(1)(a) and sue in Port Shepstone, with all the extra costs which that entails. In all probability, he will decide not to go ahead with the matter and will abandon his claim.

In the rest of this article, we wish to interrogate whether or not it is possible to reinterpret the law in such a way as to provide section $28(1)(d)$ with a somewhat wider scope than that outlined above. We wish to begin with the question of whether it is absolutely necessary for both offer and acceptance to be regarded as part of the facta probanda for jurisdictional purposes in cases based on contract.

\section{Both "offer" and "acceptance" or just "conclusion"?}

If one were to draft particulars of claim for breach of contract, one would usually allege the following:-

1 the existence of a contract between the parties;

2 the material term that was allegedly breached; and

3 the breach itself.

We submit that, for jurisdictional purposes, it may be argued that these are the essential facta probanda and that everything else is facta probantia. It is difficult to understand why both offer and acceptance should be part of the cause of action. Of course it is true that an offer is important for the formation of the contract in that it must be in existence at the time of acceptance. Provided that a valid offer was in place at the time and place of acceptance, however, why should it matter where the offer was first made? Moreover, of what possible relevance is the offer to a breach that may occur years after the acceptance of that offer? The only thing which is really important is the conclusion of the agreement. An agreement comes into

called "expedition theory" of contract, the acceptance takes place at the time and place of posting. If either the offer or acceptance had been made by means of e-mail or telefax then, according to the so-called "reception theory" of contract, it would have come into existence at the time and place of the receipt of the telefax or e-mail. It is beyond the scope of this article to examine these different theories of offer and acceptance in more detail. 
existence at the time and place of the conclusion of that agreement, and it may be argued that it is that time and place which should be relevant to jurisdiction. This view is contrary to most current interpretations of our law on this issue, which the authors of Jones and Buckle summarize as follows:

"[A] plaintiff suing on a contract must ordinarily prove ... the conclusion of the contract ... It follows ... that both the offer and acceptance must have been made in the same district."

Although most cases generally support the standard view set out in Jones and Buckle, it may be possible to upset this view, starting with an analysis of the case of Dusheiko v Milburn. ${ }^{31}$

\section{Dusheiko v Milburn - An alternative view?}

The issue of offer and acceptance as forming part of the cause of action for purposes of section 28(1)(d), has only been before the highest court of appeal on two occasions, namely the McKenzie case referred to earlier, and Dusheiko $v$ Milburn. Although the majority decisions in both of these cases are inimical to our argument, the most important support for our hypothesis comes from Rumpff JA who delivered the minority decision in Dusheiko.

Rumpff JA took issue with the definition of "cause of action" set out in Cook $v$ Gill, ${ }^{32}$ and relied on by the court in McKenzie, which reads as follows: "Cause of action has been held from the earliest time to mean every fact which is material to be proved to entitle the plaintiff to succeed - every fact which the defendant would have a right to traverse., ${ }^{33}$ He made the point that the definition equates a material fact with a fact that the defendant is entitled to deny and that it was to be expected that this definition would cause confusion.

As to the first part of the definition (that is, "every fact which is material to be proved to entitle the plaintiff to succeed"), he complained that the argument is circular. In order to know what facts are needed to be proved in order to succeed, one has to know what the cause of action is, and in order

30 There are, however, a number of cases relating to this issue where the courts have ignored offer and acceptance as material facts in relation to jurisdiction, referring only to the conclusion of the agreement. These include Millman NO v Klein 19861 SA 465 (C); Reid v Jeffreys Bay Property Holdings Pty Ltd 19763 SA 134 (C); and Rex v Nel 1921 AD 339. The latter was a criminal case in which $\mathrm{Nel}$, who had a licence for selling liquor in the Transvaal and whose premises were situated close to the Cape border, sold liquor to persons in the Cape, using a servant of his firm to collect orders. According to the facts and the findings of the court in this particular case, offer and acceptance both took place in the same place. The situation of these elements in different places was never at issue. However, the crux of the matter was actually where the contract was concluded, and one receives the impression that for the purposes of the commission of the crime at any rate, the place where the contract was concluded was the determining factor. Nevertheless, this case does not relate to jurisdiction per se.

19644 SA $648(A)$.

Supra.

This definition was paraphrased somewhat by Lord Esher in Read $v$ Brown 22 QBD 131 and adopted in its amended form by the court in McKenzie $v$ Farmers' Co-operative Meat Industries Ltd supra. 
to know what the cause of action is, one needs to know what facts are needed to be proved in order to succeed.

But over and above this problem, the learned judge complained that, by linking the concept of "cause of action" to the facts which the defendant has a right to traverse ${ }^{34}$ the standard definition treats the concept of "cause of action" in relation to jurisdiction, as it is treated in the pleadings. He believed this to be misleading. At the stage of determining jurisdiction, one is not dealing with the question of whether a summons contains a complete cause of action, but with the question of whether a court has jurisdiction over a person because certain acts or omissions by that person took place within the court's area of jurisdiction.

The judge argued that a cause of action which arises wholly within the jurisdictional area of a particular magistrate's court is a cause which exists because of an act or acts or omission which took place in the area. In the case of a delict it is the delictual act or omission. In the case of contract, it is the conclusion of the contract in that area and the breach of the contract in that area. He gave the example of a delictual case in which the agent of the defendant commits a delictual act within the area of the magistrate's court in question. An allegation that the person who committed the delictual act was the defendant's agent is essential to the cause of action, and can be traversed by the defendant. However, says Rumpff JA, the completeness of the pleadings has nothing to do with the issue of whether or not the court has jurisdiction according to law. The delict took place in the district and so the court has jurisdiction.

Apart from the dissenting judgment of Rumpff JA in Dusheiko, however, we believe that there is further support for our view that, in relation to jurisdiction involving contractual claims, offer and acceptance should be regarded as part of the facta probantia, which simply provide evidence as to the conclusion of the contract, and that it is the conclusion of the contract which should be regarded as part of the facta probanda. This involves an examination of the important case of Kings Transport $v$ Viljoen. ${ }^{35}$

\section{Kings Transport $v$ Viljoen}

Kings Transport $v$ Viljoen is an important case, since the reasoning used in this case to distinguish between the facta probanda and the facta probantia, may be extended in such a way that is allows us to reconceptualize what is meant by "cause of action arising". By doing this, it may be possible to release the magistrates' courts from the jurisdictional strait-jacket imposed by the standard interpretation of "cause of action" referred to above.

The facts of Kings Transport were simple enough. The case concerned a delictual claim in the magistrates' courts, arising out of a motor-vehicle collision which took place in Somerset West. The Kings Transport vehicle

34 In the context of pleadings, to "traverse" is to deny an allegation of fact in a pleading (see Collins English Dictionary 6ed 2004 Harper-Collins 1714

3519541 SA 133 (C) 137. 
was being driven by an employee of the company, one Du Plessis, who was acting in the course and scope of his employment at the time. The other vehicle was owned by Viljoen, who sued Kings Transport in the Somerset West magistrate's court, for damages to his vehicle. The jurisdictional basis of Viljoen's claim was that the cause of action had arisen wholly within the magisterial area of Somerset West, where the collision had occurred. Kings Transport countered that the cause of action had not arisen wholly in Somerset West, for the simple reason that Viljoen's claim was based on vicarious liability. They argued that, in order to prove vicarious liability, Viljoen had to prove that the Kings Transport driver, Du Plessis, was acting within the course and scope of his employment at the time of the collision. Kings Transport maintained that, because the contract of employment between itself and its driver, Du Plessis, had been entered into in Salt River, Viljoen's cause of action had not arisen "wholly" in Somerset West. Therefore, according to Kings Transport, Viljoen did not have jurisdiction in Somerset West. The court, however, rejected the argument by Kings Transport and stated, inter alia, as follows:

"The sole ground advanced by defendant in his special plea for resisting the jurisdiction of the Somerset West Magistrate's Court is the circumstance that the contract between himself and Du Plessis was entered into outside the district of Somerset West. Now, as I have already indicated, plaintiff is not suing defendant upon that contract; what plaintiff has to prove is that what I have called the vicarious responsibility factors obtained at the time of the collision. Upon such proof, defendant's liability to plaintiff at once arises as a matter of law. The vital enquiry thus concerns the legal relationships of defendant and Du Plessis as at that moment when, within the district of Somerset West, Du Plessis by negligence injured plaintiff. It is upon that that plaintiff's cause of action against defendant rests, and not upon where or when a contractual relationship of master and servant between defendant and Du Plessis had its origin. The fact that Du Plessis' contract of employment was concluded outside the district of Somerset West is not a fact material to plaintiff's cause of action.",36

In other words, the court in Kings Transport held that, as far as the issue of jurisdiction was concerned, the signing of the contract of employment between Kings Transport and its driver, Du Plessis, was part of the facta probantia of the case and not part of the facta probanda. It was not the fact of the signing of the employment contract, but the fact that the driver was acting within the course and scope of his employment at the time and place of the collision, that formed part of the facta probanda of this case. The signing of the contract of employment was only part of the facta probantia, that is, a piece of evidence to be adduced to prove that the driver was acting within the course and scope of his employment at the time and place of the collision.

The question which then arises is: how can the reasoning adopted in the Kings Transport case be extended in order to release magistrates' courts matters from their "jurisdictional strait-jacket" in relation to cause of action having to "arise wholly" within the district of a single court?

36 Kings Transport $v$ Viljoen supra 137. 


\section{The Kings Transport approach applied to contract}

In the case of claims based on contract there is a sequence of events which may look something like this:

Offer by the plaintiff - followed by - Acceptance by the defendant amounting to - Conclusion of the contract - followed by - Performance by the plaintiff of his obligations under the contract - followed by - failure to perform or defective performance by the defendant - amounting to - Breach of the contract.

As has been noted above, for purposes of jurisdiction in magistrates' courts matters, where reliance is placed on section $28(1)(d)$ of the Magistrates' Courts Act, the current state of our law probably requires that each and every element listed above must have occurred within the district of the magistrate's court in which action is instituted. Making use of the reasoning adopted in the Kings Transport case, it may be possible to argue that, for purposes of jurisdiction, the place the offer was first made should be considered as part of the facta probantia. After all, the offer continues in existence until such time as it lapses or is validly accepted. If it is accepted the contract is concluded. It may be argued that only the place of acceptance of the contract should be regarded as part of the facta probanda for jurisdictional purposes, since this is the place the contract is concluded.

It is not that the offer is not relevant, but for jurisdictional purposes, and using Kings Transport reasoning, the relevant question to be asked may, perhaps, be stated as follows: "At the time and place of acceptance, was there a valid offer in existence, leading to the conclusion of a valid contract?" According to this reasoning, the place the offer was first made is part of the facta probantia for jurisdictional purposes, whereas the place of acceptance is part of the facta probanda, since it is at this place that a valid contract was concluded.

\section{A STEP FURTHER OR A STEP TOO FAR?}

If one adopts the line of reasoning set out in the previous section, it may be possible to stretch the argument even further. Why should the place of conclusion of a valid contract be part of the facta probanda when it comes to jurisdiction in relation to a cause of action arising in contract? Is it not the place of breach which should be definitive as to where a cause of action based on contract arises? To put it another way, using Kings Transport reasoning, is not the relevant question to be asked the following: "At the time and place of the breach, was there a validly concluded contract in existence?" By this reasoning, it is the fact that a validly concluded contract was in existence at the time and place of the breach that is central to the cause of action, and not the fact that the contract was concluded at this or that particular place. For purposes of jurisdiction, the fact that the contract was concluded at a particular place may be regarded as part of the facta probantia. It is the existence of the contract at the time and place of the breach that forms part of the facta probanda. 
There is possible support for this rather radical view, which is to be found in the case of Thomas $v$ BMW South Africa (Pty) $L t d,{ }^{37}$ a High Court matter dealing with a claim based not on contract but on delict.

\section{Thomas v BMW South Africa (Pty) Ltd}

The matter in Thomas $v$ BMW South Africa (Pty) Ltd arose out of a collision which occurred in Newlands, Cape Town, when a faulty cruise control mechanism caused a vehicle to accelerate off the road and crash, resulting in injury to the plaintiff. The mechanism was allegedly defective when fitted, or alternatively, had been negligently fitted, to the vehicle at a factory situated in Johannesburg. This was one of those rare occasions in which a negligent act happens in one place, but the consequences manifest themselves in another.

With regard to the issue of precisely where a delict arises, the court stated as follows:

"There can be no delict in the absence of a wrongful act or omission on the part of a wrongdoer. An act or omission can be characterized as wrongful only

if it results in damnum. Until that happens an act or omission constitutes no more than 'negligence in the air'. Wrongfulness is not simply an attribute of a wrongdoer's conduct but a function of that conduct together with its consequences in relation to a particular person."

The logical conclusion to which this statement points is that the cause of action in delict can only arise once all the elements are in place. This conclusion was not the basis for the eventual decision in Thomas $v$ BMW, however. For this the court appears to have been influenced by the sentiments expressed by Dickson $\mathrm{J}$ in Moran et al $v$ Pyle National (Canada) Ltd 43 DLR (3d) 239 in the following terms, which Van Reenen J quotes in his judgment:

"Generally speaking, in determining where a tort has been committed, it is unnecessary, and unwise, to have regard to any arbitrary set of rules. The place of acting and the place of harm theories are too arbitrary and inflexible to be recognized in contemporary jurisprudence."

Van Reenen $J$ proceeded on a magisterial review of international decisions relating to matters where elements of the cause of action in delict occurred in different jurisdictions. He rejected the notion that all elements of the cause of action needed to occur within the jurisdiction of a court for it to have jurisdiction, and also the opposite view that any court may have jurisdiction if any element of the cause of action had arisen within its jurisdiction in the following terms: -

"What is strikingly apparent from the aforegoing is the absence of any support for Mr Redding's contention that a court may exercise jurisdiction in respect of a delict only if all the elements thereof have occurred within its area of

\footnotetext{
Thomas $v$ BMW South Africa (PTY) LTD supra.

Thomas v BMW South Africa (PTY) LTD supra 120B-C.

Thomas $v$ BMW South Africa (PTY) LTD supra 124A-B.
} 
jurisdiction. That approach has been described as 'too restrictive for the needs of modern times' (per Lord Pearson in the Distiller's case supra at 699) and 'this Draconian theory' (per Dickson J in Moran's case supra at 249) will result therein that in those instances where any of the elements of a delict occur in one jurisdiction, and others in another, or where one or more of the elements thereof transcend different jurisdictions, such delict will have no locus or all of them will have jurisdiction. In my view the former conclusion is totally illogical and divorced from reality and the latter might enable a court to exercise jurisdiction on the basis of even possibly the flimsiest of jurisdictional connecting factors."

The judge proceeded to set out a test involving the identification of the locus of the delict for jurisdictional purposes, in the following terms:-

"Following the example of the foreign jurisdictions referred to above, the most apparent solution appears to be to devise qualitative and quantitative criteria to determine, with reference to the elements of the delict in question - to the extent that it is possible to break a delict up into metaphysical components the court which is the most closely associated with the delict, the locus whereof has to be determined. Such criteria, however, should accord with the principles of our common law regarding jurisdiction, be consonant with developments in our case law and accommodate the demands of modern society. Bearing all this in mind, the locus of a delict for jurisdictional purposes, in my view, should be determined with reference to the materiality of and the number of the ingredients thereof which have occurred in a court's area of jurisdiction.

The fact that the judge speaks of "the locus of a delict for jurisdictional purposes", it is submitted, lends at least some degree of support to our earlier argument that a series of events leading up to a "cause of action arising" may be considered as part of the facta probantia for jurisdictional purposes. We have argued that the time and place of the final event in the chain, that is, the time and place of the breach in the case of a cause of action based on contract, should be the central focus when determining jurisdiction in magistrates' and small claims courts' matters. We could argue on similar lines that the time and place of the final event in the chain in delictual matters, that is, the time and place at which the damages arise, should determine jurisdiction in such matters in the magistrates' and small claims courts. The fact that the judge in Thomas $v$ BMW seems to be searching for a single locus of a delict for jurisdictional purposes, is in line with such an argument, although he ends up with a test which is wider but far less precise. It is submitted that this lack of precision may render it unsuitable as a workable test for practitioners, since there will always be an element of uncertainty about whether or not they have correctly isolated the "locus of the delict ... with reference to the materiality of and the number of the ingredients thereof".

It must be said that in the context of delict, it is hard to conceive of a situation in which when applying Van Reenen J's "locus" test, it will not require all the elements of the delict to have already occurred, that is, both the wrongful act and the resultant harm, in order to maximize the number of material ingredients. That being the case, it will almost always be the "forum

Thomas v BMW South Africa (PTY) LTD supra 125B-E.

41 Thomas $v$ BMW South Africa (PTY) LTD supra 125E-G. 
damnum emergens" that has jurisdiction, although it seems that Van Reenen $\mathrm{J}$ was not intending this to be the invariable result.

\section{$7 \quad$ CONCLUSION}

In conclusion, it is submitted that complex and arcane rules of jurisdiction should not be allowed to operate in such a manner so as to hinder access to justice by poor and middle-class plaintiffs. It is submitted further that the manner in which our courts have interpreted the words "if the cause of action arose wholly", which appear in section 28(1)(d) of the Magistrates' Courts Act, has led to and will increasingly lead to this unwanted outcome. We have put forward one possible argument, based upon the line of reasoning adopted in the case of Kings Transport $v$ Viljoen and supported by certain other judgments discussed in this article, by means of which magistrates' and small claims courts' jurisdiction may be released from their "jurisdictional straight-jacket". The ultimate solution to this problem, however, may lie in legislative reform. 